\section{Measurement of periodic open and shut shell movement of bivalves by the strain-gauge method ${ }^{* 1}$}

Short Paper

It is well known from old times that animals show the rhythmic behavior with about one day period and for measurement of which various devices $^{1-4)}$ suitable for each object have been used.

MORI $^{5)}$ pointed out that so many biologists including himself had an opinion that most of the marine animals live under both influences of tide and alternation of day and night. The periodic shell movement of bivalves is known to have been searched by means of the kymograph under the condition that the animals were settled to the substratum and were put in more or less constant environment ${ }^{8,7)}$, but scarcely known is the movement of the animals set in environment with changing component. The author was informed that the strain-gauge which was often used in the field of engineering could probably be applied to measure shell movement of the animals left in somewhat free condition, and then tried to test with Japanese little-neck, Tapes japonica (DESHYES).

In this case, a $\Omega$-shaped attachment on which distortion is made in according to shell movement is fitted up directly on both sides of the shell.

The gauge sticked on the upper part of the attachment can detect this minute distortion. Some force, though a little, may act as to push the opposing valves together or to pull them apart by setting the attachment. Still more, fine leading wires from the gauge and strings to make the shellfish unescapable considerably restrict his shifting it's position at the water bottom. These might have any unfabourable influence on the natural shell movement. But this method has more advantages, for example, to be able to measure the shell movement in various conditions without complicated apparatus, and to continue the measurement so far as the accidents such as the leading wire breaks never occur.

Two examples of measurement of shell movement are shown in Fig. 1. A in Fig. 1 is a record which was measured in the neighborhood of the boat harbor of our laboratory, which is located in the inner part of Matsushima Bay-natural habitat for the shellfish. It can be seen that long acting and short resting term alternates for about twenty four hours. $B$ in Fig. 1 is that of the movement of shellfish put in a water tank in the laboratory. In this figure, $a^{\prime}, a^{\prime \prime}$ and $a^{\prime \prime \prime}$ show the resting period which was established in the preceding environment, $b$ shows the nearly closed state of valves corresponding to fall of water level, and $c$ shows that $a^{\prime \prime \prime}$ is piled up on $b$. It is clear that the shellfish has a nature to react to the stimulation of a fall of water level once a day. Even from only these data, the periodic movement of the shellfish is expected to relate to the diurnal change of environment and tidal change.

Until now indoor rearing of bivalves is generally considered to be difficult, and for which it has been desired to investigate the components of environment which closely take part in the existence of the individuals. To comprehend the
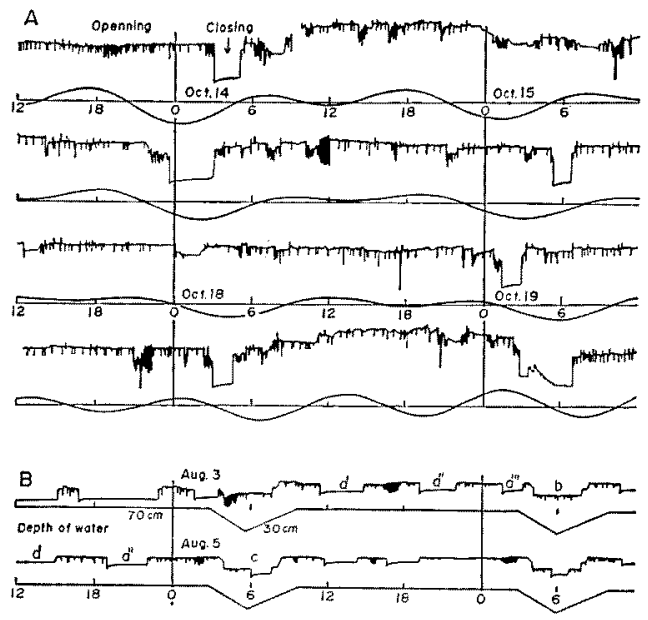

Fig. 1. A, Record in natural habitat. The wave below shows the tidal change at Ayukawa, Miyagi, Japan. B, Record in water tank with artificial change of water level shown beneath.

elements of environment requested by the animals will therefore become essential for bringing wild ones to the artificial environment. From the viewpoint, the strain-gauge seems to be useful in research for the corresponding relationship of bivalves to the environment.

The author wishes to express gratitude to Assist. Prof. Kiyonari SEkINo, Faculty of Agr., Tohoku Univ., Mr. Michio OHMorI, Seikai Reg. Fish Res. Lab., and Mr. Toshihiro IIkURA, Agr. Civil Engin. Res. Lab, from whom he was given many advices.

\section{Taketo Furn*2}

Tohoku Reg. Fish. Res. Lab., Shiogama, Miyagi, Japan.

\section{References}

1) Y. ChiBA: Biological Science (Seibutsu Kagaku), 24, 21-29 (1972).

2) S. MoRI: Rythmic Life of Animals (Dobutsu no Seikatsu Rizumu), 3rd ed., Iwanami, Tokyo, 1975, pp. 167-180.

3) S. ANDoU: Biological Science (Seibutsu Kagaku), 23, 120-127 (1972).

4) B. Morton: Proc. Malac. Soc. Lond., 38, 401-414 (1969).

5) S. MORI: Periodic Action of Animals (Dobutsu no Nisshukatsudo), Hoppo Pub]. Comp. 1949 , p. 35.

6) F. A. BRown: Am. J. Physiol., 178, 510-514 (1954).

7) M. F. BENNETT: Biol. Bull., 107, 174-191 (1954).

Received January 24, 1977

*1 ストレインダージよる二枚只の周期的閏開 㲄運動の測定,

*2 藤开武人; 東北区水産研究所 